\title{
Investment Law in the China-ASEAN Free Trade Agreement
}

\author{
Huan Qi ${ }^{*}$
}

Cooperation between China and the ASEAN has become more integrated as their common economic interests have been increasing due to globalization and recent changes in Southeast Asia. The formation and operation of the CAFTA provide incentive for investment and trade between China and the ASEAN. The objective of laws regulating to investment should promote investment, which can be realized through a liberal, facilitative and transparent investment regime. The CAFTA's investment regime continues along with the same trends of international investment agreements in general. However, in order to encourage regional integration, it needs to be improved in future practice.

\section{Keywords}

China-ASEAN Free Trade Area, CAFTA, Investment Agreement, BITs, WTO, Dispute Settlement

\section{Introduction}

In 2011, the global flows of Foreign Direct Investment ("FDI") exceeded the prefinancial crisis levels at 1.5 trillion USD and the recovery is expected to level off in 2012 at an estimated 1.6 trillion USD.1 Simultaneously, it is also projected that half of the global total FDI will flow to the developing and transitioning economies, including the least developed countries. ${ }^{2}$ Accordingly, international investment policy has taken

* Associate Professor at the Law Faculty of the China University of Political Science and Law ("CUPL"), Beijing, China. LL.B./LL.M./Ph.D. (CUPL), Diplôme d'Université, Droit en Europe (Paris 1). The author may be contacted at: qihuanhuan66@hotmail.com /Address: No.25 Xi Tu Cheng Road, Haidian District, Beijing 100088, P.R. China. This paper has been supported by the Social Science Fund of the Ministry of Education of China (11YJA820054).

1 United Nations Conference on Trade and Development ("UNCTAD"), World Investment Report 2012: Towards a New Generation of Investment Policies iii (2012), available at http://www.unctad-docs.org/files/UNCTAD-WIR2012- 
multi-dimensional shape emphasizing the balance between the rights and obligations of the host States and investors. ${ }^{3}$ In this context, the current reformation of the Association of Southeast Asian Nations ("ASEAN") is remarkable. The ASEAN has improved its internal structure by making and implementing the ASEAN Charter, aiming at establishing the ASEAN Community by 2015 and strengthened its external relations by establishing free trade areas with China, Japan, South Korea, India, Russia, Australia, New Zealand and the United States, thereby forming ' $10+1$, ' ' $10+3$, ' ' $10+8$ ' mechanisms.

Among them, the China-ASEAN Free Trade Area ("CAFTA") is noticeable considering that the total investments have exceeded USD 90 billion. Investment by Chinese enterprises in the ASEAN has rapidly increased in many types of industries. In 2011, non-financial direct investment from mainland China to ASEAN reached to 2.54 billion USD, growing up by 13.1 percent compared to the previous year resulting to the biggest market of investment abroad for Chinese enterprises.4 For the smooth functioning of this economic relation, different aspects of investment law play crucial role.

This paper analyzes investment law in the CAFTA. The author argues that revision of the existing investment law will help to protect the interests of both the investors as well as the region. This paper is composed of five sections including Introduction and Conclusion. Part two, along with the introduction of the investment legal regime as in force in China and the ASEAN, will discuss the relationship between the CAFTA, the World Trade Organisation ("WTO") rules, Bilateral Investment Treaties ("BITs") and other free trade agreements between China and the ASEAN member States. Part three will examine the definition and scope of 'investment' in the Investment Agreement since both the CAFTA and the BITs provide an excessively broad definition of 'investment' that undermines a stable and predictable legal environment. Part four will address the mechanisms available to settle disputes between the investors and the host States. Compared to BITs between China and the ASEAN member States, the CAFTA focuses more on balancing, between the sovereignty of the host States and the interests of investors, which coincides with the recent trend of dispute settlement in international investment agreements.

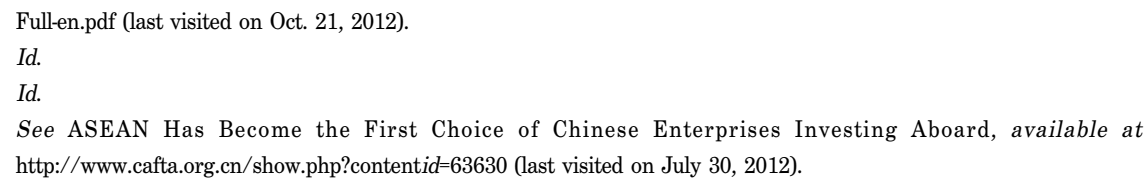




\section{Overview of Investment Laws between China and the ASEAN}

\section{A. The Emergence of the CAFTA and its Legal Framework}

The legal bases for the CAFTA are Article XXIV (5) of the General Agreement on Tariffs and Trade ("GATT") 1994 as well as Articles V and VII of the General Agreement on Trade in Service ("GATS"). Article XXIV(5) generally provides for the formation of a customs union or of a free trade area. ${ }^{5}$ In particular, Article XXIV(5), paragraph 8(2) requires that "the duties and other restrictive regulations of commerce be eliminated on substantially all the trade between the constituent territories in products originating in such territories." Moreover, Article V bis of the GATS allows the WTO Contracting Parties to enter into agreement by which the labor market can be integrated completely; Article VII of the GATS provides for flexible rules on the recognition of the qualification of service providers of another Contracting Party. Therefore, according to the GATS, Contracting Parties can deviate from the Most Favoured Nation ("MFN") in terms of regional labor market arrangements. The establishment of the CAFTA is an important step for China toward regional integration.

The signing of the Framework Agreement on Comprehensive Economic Cooperation (hereinafter Framework Agreement) in November 2002 marked a new stage of cooperation between China and the ASEAN in trade and commerce. The subsequent Trade in Goods Agreement and the Agreement on Dispute Settlement Mechanism indicate that the CAFTA has entered into the implementation phase. Apart from these agreements, the Trade in Service Agreement (January 14, 2007) and the Investment Agreement (August 15, 2009) under the Framework Agreement of Comprehensive Economic Cooperation (hereinafter Investment Agreement) were concluded. These five agreements constitute the legal grounds of the CAFTA. When the CAFTA was formally established on January 1, 2010, the trade between China and the ASEAN countries amounted to 13 percent of total global volume. Thus, the CAFTA has become the largest free trade area among developing countries. 6

In addition to the issues covered by the WTO such as trade in goods and services,

5 The General Agreement on Tariffs and Trade ("GATT") 1994 art. 24(5). It reads: "Accordingly, the provisions of this Agreement shall not prevent, as between the territories of contracting parties, the formation of a customs union or of a free-trade area or the adoption of an interim agreement necessary for the formation of a customs union or of a free-trade area."

6 See Duty-free Modern China: ASEAN try to find out the mutually beneficial (零关税 时代中国-东盟摸索互惠) (available only in Chinese), available at http://finance.ifeng.com/news/hqcj/20091231/1652071.shtml (last visited on Oct. 21, 2012). 
investment, and intellectual property protection, the Framework Agreement addresses economic cooperation in the field of agriculture, information, communications technology and human resources development. Article 5 of the Framework Agreement entitled 'Investment' reads:

[t]o promote investments and to create a liberal, facilitative, transparent and competitive investment regime, the Parties agree to: (a) enter into negotiations in order to progressively liberalize the investment regime; (b) strengthen co-operation in investment, facilitate investment and improve transparency of investment rules and regulations; and (c) provide for the protection of investments. ${ }^{7}$

Trade in goods lies at the core of the CAFTA. The Trade in Goods Agreement regulates issues such as tariff reduction and non-tariff measures between China and ASEAN members. 8

The Agreement on Dispute Settlement Mechanism has 18 articles and one annex, covering a series of issues including scope and coverage, consultations, conciliation or mediation, appointment, composition, functions, proceedings of arbitral tribunals, and compensation and suspension of concessions or benefits. This Agreement is modeled after the dispute settlement mechanism of the WTO. ${ }^{9}$

The Trade in Service Agreement attempts to enhance co-operation in services between the Parties in order to improve efficiency and competitiveness, as well as to diversify the supply and distribution between the Parties. The Agreement takes into account sensitive sectors of the parties giving special and distinctive treatment and flexibility for the newly joined ASEAN members such as Cambodia, Lao PDR, Myanmar and Vietnam.10 This Agreement is similar to the mode of the GATS and that of the ASEAN Framework Agreement on Services ("AFAS"). The AFAS, which is also referred to as GATS-Plus, asks the ASEAN member States to liberalize trade in service beyond the GATS.11

The objectives of the Investment Agreement are both to promote investment flows and to create a liberal, facilitative, transparent and competitive investment regime

7 Framework Agreement art. 5.

8 It has 23 articles and three annexes, mainly on tariff reduction and elimination, modification of concessions, quantitative restrictions and non-tariff barriers, safeguard measures, acceleration of commitments, general exceptions, security exceptions, institutional arrangements and review. See The Trade in Goods Agreement, available at http://www.aseansec.org/16646.htm (last visited on Oct. 21, 2012).

9 See The Agreement on Dispute Settlement Mechanism, available at http://www.aseansec.org/16635.htm (last visited on Oct. 21, 2012).

10 It has 33 articles including definitions and scope, obligations and disciplines, specific commitments, etc.

11 Miaoying Chen, On the Legal Program of the Liberalization of Service Trade in AFTA, ARound SouTHEAST ASIA 31 (2009), available at http://mall.cnki.net/magazine/Article/DLYZ200901008.htm (last visited on Oct. 21, 2012). 
between the ASEAN and China.12 In order to settle the disputes between the Contracting Parties, they will apply the provisions of the Agreement on Dispute Settlement, 13 while disputes between a Contracting Party and an investor will be settled according to the Investment Agreement.14

\section{B. Bilateral Investment Treaties between China and the ASEAN Member States}

Beginning with the BIT between China and Thailand in 1985, China concluded BITs with all the ASEAN member States by 2001.15 Though there are provisions regarding the duration for which the BITs shall remain in force, almost all these BITs stipulate that unless there is a notice from either of the Contracting Party to terminate the agreement one year before the expiration, the agreements shall continue in force. 16

Judging from the content, the BITs between China and the ASEAN member States belong to traditional bilateral investment protection systems of developing countries, containing definitions and scope of investment and investors, MFN provisions, Fair and Equitable Treatment to investors and investment, conditions for expropriation and standards of compensation, repatriation of capital and returns, subrogation and the methods, institutions and procedures for investment disputes settlement. However, there are almost no provisions on liberalization or facilitation of investment such as those relating to market access or National Treatment except for the China-Myanmar BIT.17 These BITs are the legal basis for establishing friendly investment cooperation between China and the ASEAN member States.

12 It provides a comprehensive legal system safeguarding investments in the CAFTA such as National Treatment, MFN, Fair and Equitable Treatment, expropriation, compensation for losses, transfers and repatriation of profits, transparency, facilitation and liberalization of investment and provision on investment disputes. See The Investment Agreement, available at http://www.aseansec.org/22974 (last visited on Oct. 21, 2012).

13 Id. art. 13.

14 Id. art. 14.

15 The effective dates of the BITs between China and ASEAN member States are following: Thailand (Dec. 13, 1983), Singapore (Feb. 7, 1986), Malaysia (Mar. 31, 1990), The Philippines (Sept. 8, 1995), Vietnam (Sept. 1, 1993), Laos (June 1, 1993), Indonesia (Apr. 1, 1995), Cambodia (Feb. 1, 2000), Brunei (Nov. 17, 2000), and Myanmar (May 21, 2002).

16 BIT (P.R.C.Thail.) art. 10; BITs (P.R.C.-Vietnam, Laos \& Cambodia) art. 10; BITs (P.R.C.-Malay., Phil. \& Indon.) art. 13; BITs (P.R.C.-Brunei \& Myan.) art. 14; BITs (P.R.C.-Sing.) art. 16.

17 BIT (P.R.C.-Myan.) art. 3.2. It stipulates a conditional National Treatment, that is, without prejudice to its laws and regulations, one Contracting Party shall render the investment and activities related to the investment in its territory of investors of the other Contracting Party treatment no less than that provided to its own domestic investors. 


\section{Relationship among the Investment Agreement of the CAFTA, the WTO rules, the BITs and Other Free-Trade Agreements}

In practice, the China-ASEAN BITs and the Investment Agreement of the CAFTA are simultaneously applicable. While the BITs do not include provisions addressing their relationship with other agreements, there is a clear stipulation in the Investment Agreement.

First, the Investment Agreement further reaffirms the rights, obligations and undertakings of each Party under the WTO; it controls other multilateral, regional and bilateral agreements and arrangements. Second, according to Article 23 of the Investment Agreement, 18 provisions in the WTO Agreement, the BITs and other freetrade agreements shall prevail over those in the Investment Agreement.

Concerning the relationship between each Free Trade Agreement ("FTA") and the CAFTA, Article 84(1) of the China-Singapore FTA ("CSFTA") states that: "The provisions of that agreement [CSFTA] shall, mutatis mutandis, be incorporated into and form an integral part of this Agreement [CAFTA]." 19 However, any rights, obligations, restrictions or exceptions contained in the ASEAN-China Investment Agreement that do not relate to either China or Singapore shall accordingly be inapplicable. In the event of any inconsistency between the ASEAN-China Investment Agreement and the FTA, the provisions of the latter shall prevail.20 Furthermore, Article 30(2) of the Vienna Convention on the Law of Treaties ("VCLT") will be applied to general relationship between the BITs and the Investment Agreement.

CAFTA art. 23. It reads: "Nothing in this Agreement shall derogate from the existing rights and obligations of a Party under any other international agreements to which it is a party."

19 The Free Trade Agreement between China and Singapore ("CSFTA") art. 84(1). It reads: "Upon the conclusion of the investment agreement between ASEAN and China pursuant to Article 5 of the Framework Agreement on Comprehensive Economic Co-operation between ASEAN and the People's Republic of China (ASEAN-China Investment Agreement), the provisions of that agreement shall, mutatis mutandis, be incorporated into and form an integral part of this Agreement unless the context otherwise requires."

20 Id. art. 84(3). It reads: "For greater certainty, any rights, obligations, restrictions or exceptions contained in the ASEAN-China Investment Agreement that do not relate to either Party shall accordingly be inapplicable under this Agreement. Notwithstanding Article 112 (Relation to Other Agreements), in the event of any inconsistency between the ASEAN-China Investment Agreement and this Agreement, the provisions of this Agreement shall prevail." Id. art. 112. It reads: "1. The Parties affirm their existing rights and obligations with respect to each other under existing bilateral and multilateral agreements to which both Parties are parties, including the WTO Agreement. 2. In the event of any inconsistency between this Agreement and any other agreement to which both Parties are parties, the Parties shall immediately consult with each other with a view to finding a mutually satisfactory solution." 


\section{Definition and Scope of 'Investment' in the Investment Agreement}

\section{A. 'Asset-based' Definition of Investment}

'Investment' is a key term in international investment agreements. After an investor enters into the host State, it is crucial to define the scope and coverage of 'investment.' High level of protection is also important because it will influence the assurance to be given by the host State on whether the international investment agreement can provide more transparent, stable and certain conditions to foreign investment. 21 Today, a broad 'asset-based' definition of investment dominates in most international and bilateral investment treaties and has become an important issue of interpretation in international arbitration. Both China-ASEAN BITs and the Investment Agreement adopt the 'assetbased' definition of investment and 'open' model, stipulating that investment means the following five categories of asset/property: (1) movable and immovable property and any other property rights such as mortgages, liens or pledges; (2) shares, stocks and debentures and any other kind of interest in companies; (3) claims to money or to any other performance having an economic value; (4) intellectual property rights and goodwill; and (5) business concessions conferred by law or under contract permitted by law, including concessions to search to cultivate, extract or exploit natural resources. 22 However, these agreements also limit the scope of investment to some extent. They are as follows.

First, all definitions in these agreements require that these investments be recognized by the host State based on its applicable law.23 For example, the China-Malaysia BIT stipulates that in respect to investments made in Malaysia, the term 'investment' shall refer to "all investments made in those assorted as the 'approved items' by the appropriate department of Malaysia in accordance with its legislation and administrative practice." 24 Meanwhile, investments made in China, refers to "all investments approved by the appropriate examination and approval authority of the People's Republic of China in accordance with its legislation and administrative

\footnotetext{
21 For details on the definition of 'Investment,' see International Investment Agreements: the scope and definition of “investment” and 'investor,' (国际投资协定: “投资”和“投资者”的范围与定义) (available only in Chinese), available at http://cts.nankai.edu.cn/html/yjry/gsq6.pdf (last visited on Oct. 21, 2012).

22 BITs (P.R.C.-Vietnam, Laos, Cambodia, Malay., Phil., Indon., Brunei, Myan. \& Sing.) art. 1.1; BIT (P.R.C.-Thail.) art 1.3 .

23 Id. at $1^{\text {st }}$ sentence.

24 BIT (P.R.C.-Malay.) art. 1.1.
} 
practice." 25 This kind of stipulation has the following three advantages: (1) it guarantees that all laws and regulations shall be applied throughout the course of investment; (2) it emphasizes that only investments permitted under the law of the host State can be protected by the BIT; and (3) both domestic and foreign investors are required to abide by the domestic laws to ensure fair competition.

Second, the BITs of China with the Philippines, Laos and Vietnam contain the simplest provisions regarding the investment system. ${ }^{26}$

Third, in BITs between China, Cambodia, Myanmar, Brunei, Malaysia, Singapore, Thailand and Indonesia, "every kind of asset" is inclusive, which denotes that assets include all things having economic value. One example is the general explanation laid down in Article 1(d) of the Investment Agreement.27 The phrase 'including mainly' is used in other BITs. While these BITs represent the open mode of definition, this qualifying language makes the meaning of investment less clear. ${ }^{28}$

Last, BITs between China and Malaysia, Brunei and Myanmar, as well as the Investment Agreement ${ }^{29}$ stipulate that any alteration of the form in which assets are invested shall not affect their classification as investments. 30 The China-Malaysia BIT provides that such alteration shall not be "contrary to the approval granted in respect of the assets originally invested." 31 The Investment Agreement also clarifies the nature of returns of investment, stating that "returns that are invested should be treated as investments and any alteration of the form in which assets are invested or reinvested shall not affect their character as investments." 32 The Investment Agreement would reflect the development of the definition and scope of investment in recent international

25 Id.

26 BITs (P.R.C.-Phil., Laos \& Cambodia) art 1.1. It reads: "(a) movable and immovable property and other property rights( Phil., Laos \& Vietnam); (b) shares in companies or other forms of interest in such companies (Phil., Laos \& Vietnam); (c) claims(Phil.)/a claim (Laos \& Vietnam) to money or to any performance having an economic; (d) copyrights, industrial property, know-how and technological process (Phil., Laos \& Vietnam); (e) concessions conferred by law, including concessions to search for or to exploit natural resources (Phil., Laos \& Vietnam)."

27 Investment Agreement art. 1.1(d). It reads: “... investment' means every kind of asset invested by the investors of a Party in accordance with the relevant laws, regulations and policies 1 of another Party in the territory of the latter including, but not limited to, the following:..."

28 BITs (P.R.C.-Phil., Laos \& Vietnam) art. 1.1. It provides that: “... "investments' means..., including mainly..."

29 BIT (P.R.C.-Myan.) art. 1.1 provides that: "Any change in the form in which assets are invested does not affect their character as investments."

30 BITs (P.R.C.-Malay., Brunei \& Myan.) art. 1.1.

31 BIT (P.R.C.-Malay.) art. 1.1. It provides that: "Any alteration of the form in which assets are invested shall not affect their Classification as investments, provided that such alteration is not contrary to the approval granted in respect of the assets originally invested.”

32 Investment Agreement art. 1.1(d). It reads: For the purpose of the definition of investment in this Sub-paragraph, returns that are invested should be treated as investments and any alteration of the form in which assets are invested or reinvested shall not affect their character as investments. 
investment treaties, while the earlier China-ASEAN BITs offer a much lower level of protection.

\section{B. Definition and Scope of 'Investment' in Model US BITs}

The 2012 US Model BIT ("Model BIT") inherits the definition of 'investment' from its 2004 version, which is the most widely used today. First, in its general description, 'investment' is limited to every asset with the characteristics of an investment regardless of the forms of investment. Article 1 of the Model BIT provides that:

'Investment' means every asset that "an investor owns or controls, directly or indirectly, that has the characteristics of an investment, including such characteristics as the commitment of capital or other resources, the expectation of gain or profit, or the assumption of risk." 33

As to the content of investment, the Model BIT borrows the from Article 1139 of the North American Free Trade Agreement ("NAFTA"), but removes its restrictive conditions. Additionally, the Model BIT definition also includes futures, options, and other derivatives, which are purely indirect investment. ${ }^{34}$

Compared with the Model BIT, the definition given in the Investment Agreement is more suitable for the development of economy and investment practice in China and the ASEAN. Even though the Model BIT continues to evolve in favor of investors, it has to consider the balance between the public interest and the interests of investors. For example, Article 18 of the Model BIT contains exceptions based on 'Essential Security,' which aims at preventing excessive protection to investment from harming public interest. 35 However, the Model BIT also requires that such essential security exception judged by each party shall not be exempted from judicial or arbitral review. Therefore, with respect to China and the ASEAN, it is better to create a stable and predictable legal environment rather than giving unduly broad definition to investment.

33 Model BIT(2012) art. 1 (16 th term).

34 "Five functional categories of investment are distinguished in the international accounts: (1) direct investment; (2) portfolio investment; (3) financial derivatives (other than reserves) and employee stock options; (4) other investment; and (5) reserve assets." See IMF, Balance of Payments and International InVEstment Position Manual $\uparrow 6.1$ ( $6^{\text {th }}$ ed. 2008).

35 The Model BIT art. 18. It provides that: "Nothing in this Treaty shall be construed: 1 . to require a Party to furnish or allow access to any information the disclosure of which it determines to be contrary to its essential security interests; or 2. to preclude a Party from applying measures that it considers necessary for the fulfillment of its obligations with respect to the maintenance or restoration of international peace or security, or the protection of its own essential security interests." 


\section{Dispute Settlement Mechanism between Investors and the Host State}

\section{A. Provisions in BITs between China and the ASEAN Member States}

The BITs between China and the ASEAN countries provides that the dispute shall be settled in the following three ways:

\section{Negotiation.}

All China-ASEAN BITs stipulate that any dispute arising from investment between investors and the host State shall be settled amicably through negotiation to the best of their ability and generally a period of six months is allocated at this stage. 36

\section{Submission to the Court of the Host State}

Article 9(2) of the China-Cambodia BIT says that: "If the dispute cannot be settled through negotiations within six months, either party to the dispute shall be entitled to submit the dispute to the competent court of the Contracting party accepting the investment." The BITs between China and Burma, Laos, Singapore, Indonesia and Vietnam have similar provisions.37 Besides, there are also scopes for the concerned investors that sometimes they are permitted to file a complaint with and seek relief from the competent administrative authority or agency of the Contracting Party. 38

\section{International Arbitration}

Some BITs directly stipulate that if the dispute cannot be settled through negotiation within six months, the investor can proceed with international arbitration. ${ }^{39}$ Article 9.3 of the China-Burma BIT provides that any dispute shall be submitted to the International Center for Settlement of Investment Dispute ("ICSID") or an ad hoc arbitral tribunal. 40

There are two kinds of formulations as to the scope of disputes that can be brought to arbitration. The first formulation contains: (1) disputes regarding the amount of

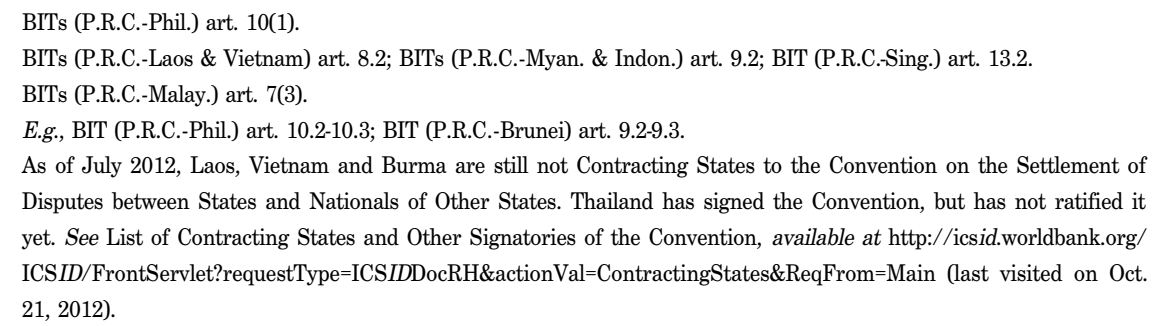
Disputes between States and Nationals of Other States. Thailand has signed the Convention, but has not ratified it yet. See List of Contracting States and Other Signatories of the Convention, available at http://icsid.worldbank.org/ ICSID/FrontServlet?requestType=ICSIDDocRH\&actionVal=ContractingStates\&ReqFrom=Main (last visited on Oct. $21,2012)$. 
compensation; and (2) disputes whose parties have agreed to refer to arbitration. 41 The second formulation is "disputes arising out of investment between investors and the host State" 42 or any legal dispute "in connection with an investment in the territory of the other Contracting Party." 43

Some BITs make it clear that only disputes concerning the amount of compensation for expropriation can be brought to the ad hoc arbitral tribunal.44 For example, according to Article 7.1 of the China-Malaysia BIT, the competent court of the host State or an international arbitral tribunal is authorized to review the amount of compensation. 45

Other BITs stipulate that disputes can be settled through international arbitration in accordance with the arbitration clause agreed upon by the parties. 46

Although disputes can be brought to arbitration with the consent of the host State, most BITs permit the host State to require the investor to exhaust the domestic administrative and reconsideration procedure. 47 However, if the parties agree to or have submitted the dispute to the court of the host State, the arbitral procedure shall no longer apply. 48

If the tribunal cannot be constituted, the Parties can invite the following figures for assistance: (1)President of the International Court of Justice; 49 (2) Chairman of the International Chamber of Commerce;50 (3) Secretary-General of the International Center for Settlement of Investment Dispute ("ICSID”);51 or (4) Chairman of the International Arbitration Institute of the Stockholm Chamber of Commerce. 52

The arbitral tribunal can make its own procedure or refer to the Convention on the Settlement of Disputes between States and Nationals of Other States (hereinafter

41 BIT (P.R.C.-Phil.) art. 10.2; BIT (P.R.C.-Malay.) art. 7.4.

42 BIT (P.R.C.-Brunei) art. 9.1.

43 BIT (P.R.C. Burma) art. 9.1.

44 BIT (P.R.C.-Burma) art. 8.3.; BIT(P.R.C.-Laos) art. 8.3; BIT (P.R.C.-Indon.) art. 9.3; BIT(P.R.C.-Vietnam) art. 8.3; and BIT (P.R.C.-Sing.) art. 13.3.

45 BIT (P.R.C.-Malay.) art. 7.4, available at http://tfs.mofcom.gov.cn/aarticle/h/at/201002/20100206778586.html (last visited on Oct. 21, 2012).

46 BIT (P.R.C.-Malay) art. 7.5. It reads: "In addition to the foregoing provisions of this Article, disputes between investors of a Contracting Party and the investors of the other Contracting Party in whose territory the investment was made may be settled by international arbitration in accordance with the arbitration clause between the parties."

47 BIT (P.R.C.-Brunei) art.9.2; BIT (P.R.C.-Burma) art. 9.3.

48 BIT (P.R.C.-Burma) art. 9.3; BIT (P.R.C.-Cambodia) art. 9.3; BIT (P.R.C.-Laos) art. 8.3; BIT (P.R.C.-Sing.) art. 13.3; and BIT (P.R.C.-Vietnam) art. 8.3.

49 BIT (P.R.C.-Phil.) art. 10.3.

$50 \quad$ BIT (P.R.C.-Brunei) art. 9.3.

51 BIT (P.R.C.-Cambodia) art. 9.4; BIT (P.R.C.-Laos) art. 8.4; BIT (P.R.C.-Brunei) art. 9.4; and BIT (P.R.C.-Vietnam) art. 8.4

52 BIT (P.R.C.-Malay) art. 7.4; BIT (P.R.C.-Sing.) art. 13.5. 
Washington Convention). 53 However, the China-Malaysia BIT states that the arbitral tribunal may also determine its own procedure by referring to the Arbitration Rules of the United Nations Commission on International Trade Law. 54

Applicable laws in dispute settlements include domestic laws of the host States, BITs and recognized principles of international law. Article 9.7 of the China-Cambodia BIT provides that the tribunal shall adjudicate in accordance with "the law of the Contracting Party to the dispute accepting the investment including its rules on the conflict of laws, the provisions of this Agreement, as well as the generally recognized principles of international law accepted by Contracting Parties." 55 However, the BITs between China and the Philippines, Singapore and Indonesia do not include provisions concerning applicable law. All Chinese BITs eventually provide that the award by the tribunal is final and binding. 56

\section{B. Stipulation in the Investment Agreement of the CAFTA}

Investment disputes arise mainly because the host State violates its obligation under National Treatment, MFN, Treatment of Investment, Expropriation, Compensation for Losses and Transfers and Repatriation of Profits. 57 Such breach causes loss or damage to the investor with respect to the management, conduct, operation, or sale or other disposition of an investment. 58 Article 14.2 lists the exceptions, which provides that Article 14 shall apply neither to investment disputes arising out of events which occurred, nor to investment disputes which had been settled, or which were already under judicial or arbitral process, prior to the entry into force of the Investment Agreement. 59

The Investment Agreement manifests the following characteristics concerning dispute settlement. First, Negotiation is of prime and necessary importance. 60 The duration for a negotiation is generally six months.

Second, if the dispute cannot be settled within six months, the investor can choose to bring the dispute before the judicial or administrative court of the host State or to arbitration. ${ }^{61}$ In taking the interests of the developing countries into consideration, the

59 There is no similar description in the BITs.

60 Investment Agreement art. 14.3.

61 Id. art. 14.4. 
Investment Agreement would emphasize on exhausting local remedies and retain the governing power with the host State in developed nations. ${ }^{62}$ However, in all other circumstances, the Investment Agreement not only allows an investor to go straight to arbitration, but also creates more opportunities to settle the case in arbitration. 63

Third, a "fork-in-the-road" clause allows an investor to choose between local remedies and international arbitration. 64 However, once he chooses arbitration or domestic litigation, the investor cannot switch to another forum. This kind of clause is also referred to as the "one and final choice." 65 In fact, arbitral tribunals usually interpret the "fork-in-the-road" clause more strictly. For example, in Vivendi v. Argentina, 66 Alex Genin v. Estonia67 and Middle East Cenent v. Egypt68 cases, the arbitral tribunals opined that legal procedures in domestic courts and international arbitrations are two different things with different causes of actions. Therefore, after seeking local remedies with almost no restrictions, investors may initiate arbitration before the ICSID on the ground that the host State has breached a treaty. 69

Fourth, arbitration clauses take the following four shapes in the Investment Agreement:

1. The parties can choose to submit the dispute to ICSID for arbitration if both the host and the home states are Contracting States of the Washington Convention;

2. The parties can ask for arbitration based on the ICSID Additional Facility Rules if either the host or the home state is a Contracting State of the Washington Convention;

3. The parties can go to arbitration under the rules of the United Nations Commission on International Trade Law ("UNCITRAL");70 and

62 Id. art. 14.4(a).

63 Id. art. 14.4(b)

64 Id. art. 14.5. "Fork-in-the-road" clauses apply only to Indonesia, the Philippines, Thailand and Vietnam.

65 Chinese scholars usually use the expression "fork-in-the-road." See The New Development in International Investment Law and the New Practice in China's Bilateral Investment Treaties (载于陈安主编: 国际投资法的新发展与中 国双边投资条约的新实践) 226-231 (Chen An ed., 2007). The expression used by the ICSID is "forum-selection provision." See C. Schreuer: Investment Treaty Arbitration and Jurisdiction over Contract Claims-the Vivendi I Case Considered, available at http://www.univie.ac.at/intlaw/wordpress/pdf/76_cschapter_76.pdf (last visited on Oct. 21, 2012). See Investment Agreement art. 14.5.

66 Compañía de Aguas del Aconquija S.A. \& Vivendi Universal S.A. v. Argentine Republic, ICSID Case No. ARB/97/3, Decision on Annulment, $\uparrow 55$.

67 Alex Genin and others v. Republic of Estonia, ICSID Case No. ARB/99/2, Award, ๆ 321-322.

68 Middle East Cement Shipping and Handling Co. S.A. v. Arab Republic of Egypt, ICSID Case No. ARB/99/6, $\uparrow 71$.

69 Chen An (ed.), supra note 65, at 227.

70 The United Nations Commission on International Trade Law ("UNCITRAL") was established by the General Assembly in 1966. See G.A. Res. 2205 (XXI), U.N. Doc. A/6594 (Dec. 17, 1966). The Commission adopted the UNCITRAL Arbitration Rules on April 28, 1976. 
4. The parties can go to any other arbitration institutions and use any arbitration rules, if the disputing parties agree.71

This shows that the Investment Agreement is in accordance with current regional trade agreements and typical bilateral investment agreements such as the NAFTA and the 2004 and 2012 US Model BIT.72 As can be seen from the 2004 US Model BIT, however, the Unites States believes that an appellate body should be established which shall be empowered to review awards rendered by the tribunals.73 On the other hand, under the 2012 Model BIT, the Parties would consider whether awards rendered under the BIT should be subject to that appellate mechanism. ${ }^{74}$ However, neither the BITs between China and ASEAN member States, nor the Investment Agreement has dealt with an appellate mechanism.

Considering the economic power of China and the ASEAN, high standard investment rules may not be harmful for China since those rules are in favor of protecting investors and eventually serve China's interests. In order to obtain the ultimate goals of the Investment Agreement, the politics lying between China and the ASEAN should be fully considered. First, because the political systems of China and the ASEAN member States are quite different, the harmonious coexistence is of great importance for their mutual prosperity since the interdependence is the key to the economic and social development. Second, with the formation of the CAFTA, the ASEAN has become influential enough to be the third largest trade partner of China; China also became the fourth largest trade partner of the ASEAN. For further development, they should be more independent and creative.

In short, the direct legal protection by the Investment Agreement will attract more foreign capital. Since the investors may feel that they are in a disadvantaged situation in the host State, the host State should fulfill its commitment to the investor with goodwill. At the same time, the Investment Agreement should give more consideration to strike the balance between the interests of investors and the sovereignty of the host State. Even in that case, however, some limitations should be imposed on the foreign investment activities not to abuse the international arbitration mechanism. If mechanically applying the investment agreement or concession agreement, the arbitral tribunal would just

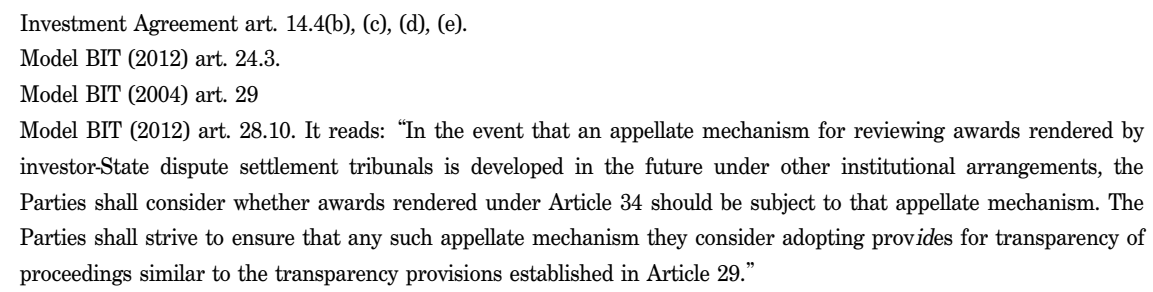


focus on the breach of the treaty by the host State neglecting the needs of its core public policy. The Investment Agreement should also consider the issue of public policy to continue in line with the global trend.75

\section{Conclusion}

While the ASEAN is the sixth largest economic body in the world, the CAFTA is not only the biggest free trade area among developing countries, but also a model of the "south-south cooperation." 76 Ever since the formation of the CAFTA, China has established five overseas economic and trade cooperation areas, including the ChinaASEAN Cooperative Fund and the China-ASEAN Interbank Association within the ASEAN. These initiatives have established important platforms for cooperation in investment and financing. After opening of the markets to each other, industrial cooperation between China and the ASEAN has become an important goal of the CAFTA to recognize this win-win situation. Today, China-ASEAN economic cooperation is fast changing from trade to investments. Furthermore, the ASEAN's investment in China has been replaced by the China's investment in the ASEAN.77 At the 44th ASEAN Economic Ministers Meeting, the ASEAN asked China to invest more in their region. ${ }^{78}$ For the regional prosperity, China should focus more on the bilateral cooperation with the ASEAN Community than before. Indeed, both China and the ASEAN have common interests and responsibilities not only for economic reasons, but also due to strategic partnership between them. Eventually, the investment law mechanism will be more important in the CAFTA region in the future.

75 See The IPFSD's guidance on the IIAs: design options, in UNCTAD, supra note 1, at xxix.

76 See United Nations, South-South Cooperation in International Investment Agreements 36 (2005), available at http://unctad.org/en/Docs/iteiit20053_en.pdf (last visited on Oct. 21, 2012)

77 See Investment from Our Country to ASEAN Speeding Up, and 10 Billion Dollars from ASEAN Fund Giving Priority to Interworking (我国投资东盟提速东盟基金 100 亿美元优先互联), (available only in Chinese) available at http://news.hexun.com/2012-07-13/143522187.html (last visited on Oct. 21, 2012).

78 See ASEAN wants more investment, tourists from China, available at http://www.asean-china-center.org/ english/2012-08/29/c_131814808.htm (last visited on Oct. 21, 2012). 
